\title{
THE FRAMEWORK FOR PARTICIPATION: A RESEARCH TOOL FOR EXPLORING THE RELATIONSHIP BETWEEN ACHIEVEMENT AND INCLUSION IN SCHOOLS*
}

\author{
Kristine Black-HaWKins ${ }^{* *}$ \\ University of Cambridge, Reino Unido \\ kb10006@cam.ac.uk
}

\begin{abstract}
This article examines the Framework for Participation: a research tool established to support a recently completed study. The research was undertaken to explore the relationship between achievement and inclusion because headteachers and teachers in some schools continue to resist becoming more inclusive in their student intake on the grounds that doing so has a negative effect on the academic achievement of other students and will lower overall standards. Embedded in these professional concerns are a number of assumptions about the nature of educational inclusion and achievement, as well as how they affect each other and how they might be measured. Therefore, the aim of the research was to gain a nuanced understanding of the relationship between inclusion and achievement. As part of this work, the Framework was devised, providing a valuable structure for the collection, analysis, and presentation of detailed qualitative and quantitative data within a multi-site case study approach. The article explores the development of the Framework's principles, purposes, and structure, and describes how it was used in the project. In doing so, it examines ways in which the use of the Framework in case study research is methodologically distinct from other studies with similar concerns and interests.
\end{abstract}

Keywords: General methodology, Qualitative methods, Educational measurement

\section{EL MARCO PARA PARTICIPACIÓN: UNA HERRAMIENTA DE INVESTIGACIÓN PARA EXPLORAR LA RELACIÓN ENTRE LOGROS Y PARTICIPACIÓN EN LOS COLEGIOS}

RESUMEN: Este artículo examina el Marco para Participación: una herramienta de investigación establecida para apoyar un estudio recientemente completado. La investigación fue emprendida para explorar la relación entre logros e inclusión porque los profesores-jefe y los profesores en algunos colegios continúan resistiéndose a ser más inclusivos en la captación de estudiantes bajo los

This article was first published in Kristine BlackHawkins (2010) The Framework for Participation: a research tool for exploring the relationship between achievement and inclusion in schools, International Journal of Research \& Method in Education, 33:1, 21-40, DOI: 10.1080/17437271003597907. Link: http://dx.doi.org/10.1080/17437271003597907

** University Lecturer in Inclusive Education, Faculty of Education, University of Cambridge. 
fundamentos de que hacerlo tiene un negativo efecto en los logros académicos de otros estudiantes y ello bajaría el estándar de todos. Por tanto, el objetivo de la investigación era ganar un matiz de entendimiento de la relación entre inclusión y logros. Como parte de este trabajo, el marco fue concebido proveyendo una valiosa estructura para la recolección, análisis y presentación de información cualitativa y cuantitativamente detallada dentro de una aproximación de un estudio de escenarios múltiples. El artículo explora el desarrollo de los principios, propósitos y estructura del Marco, y describe como fue usado en el proyecto. Al hacerlo, examina las formas en que dicho uso del Marco en investigación de estudio de casos es metodológicamente distinto respecto a otros estudios con similares preocupaciones e intereses.

\section{Palabras clave: Metodología general, Métodos cualitativos, Medición escolar}

Understandings of educational inclusion and achievement are partly shaped by shifting social, economic, and political circumstances, whether local, national, or global in nature. In England, as elsewhere, politicians have been increasingly concerned about the costs and outcomes of the education system in terms of its contribution to the nation's economic wealth and well-being. Although governments in different countries have responded in a variety of ways to these pressures, the major structural reforms that took place at the end of the twentieth century shared certain characteristics. These emphasized the principles of competition and choice, which together were intended to raise the academic standards of individual students, schools, and nations. Mechanisms of accountability have also been an essential component of this "marketisation of education". ${ }^{1}$ In England, for example, these have included the measurement of children's academic performance, at ages 7,11, 14 (now abolished), and 16, through standard tests and publication of the results in performance tables. Alongside these reforms, another rather different set of large-scale educational developments have taken place in many countries. That is, even whilst national governments have maintained this emphasis on competition, choice, accountability and standards, they have also enacted policies to promote more inclusive educational systems. Tensions have then emerged as a result of conflicts between principles that, on the one hand, underpin market-based reforms and, on the other hand, are based on values of equity and social justice. ${ }^{2}$

\section{BACKGROUND TO THE RESEARCH PROJECT}

Improving both inclusion and achievement are clearly worthwhile and important educational aims, and this dual focus on the most vulnerable students and on all students is a welcome development. ${ }^{3}$ However, a lack of clarity about meanings can make it difficult for teachers to know how best to proceed in developing policies and practices that will encourage schools to be highly

Power, S., and Whitty, G. Market forces and school cultures. In: School culture, Prosser, J. (ed.), London: Paul Chapman, 1999, pp. 15-29.

Rouse, M., and Florian, L. "Inclusive education in the marketplace", in: International Journal of Inclusive Education 1, no. 4, 1997, pp. 323-336; Audit Commission. Statutory assessment and statements of SEN: in need of review? London: HMSO, 2002; House of Commons, Education and Skills Committee. Special educational needs. Third Report of Session 2005-06, Vol. I (HC 478-I), 2006, London: HMSO.

Florian, L. Reimagining special education. In: The Sage handbook of special education, Florian, L. (ed.), London: Sage, 2007, pp. 7-20. 
inclusive in their student intake whilst supporting the highest achievements from all their students. Furthermore, such policies generally present a particular and somewhat narrow interpretation of both concepts. That is, inclusion is taken to mean the process of increasing the numbers of students attending mainstream schools who, in the past, would have been prevented from doing so because of their identified special educational need and/or disability. Meanwhile, achievement is usually seen in terms only of raising academic standards as measured by national tests and examinations, rather than more broadly so as to encompass social, emotional, creative, and physical achievements as well. As noted in a recent House of Commons (2006) Select Committee Report: "Regardless of the theory, in practice the evidence clearly demonstrates that SEN (special educational needs) and the raising attainment agenda sit very uncomfortably together at present". ${ }^{4}$ The implication is that achievement and inclusion are incompatible.

This article explores the methodological approach that was developed for a recently completed study. 5 The aims of the study were to examine the tensions noted above in the relationship between achievement and inclusion in schools, and to reflect on how they might be resolved. Three overarching questions shaped the research. These were: (1) What is the relationship between achievement and inclusion? (2) How might a school's policies and practices raise the achievement and inclusion of all its students? and (3) What strategies might help teachers to understand, monitor, and develop all students' achievement and inclusion? To support a nuanced response to these questions, which would be meaningful to practitioners as well as to policy-makers, the work focused not on existing and generalized inequities in current national systems, but on a detailed understanding of the ways in which a small number of individual schools set out to accommodate variations amongst all their learners so that all can achieve, whether or not they have been identified as having disabilities, learning difficulties, or special educational needs. Thus, the study was guided by Gould's ${ }^{6}$ insight that trends (in this case towards greater inclusion and achievement) are about changes in variation within complete systems, rather than a complete process or entity moving in a single direction.

In line with these arguments, the research team decided to use the structure of a multi-site case study analysis to collect both detailed qualitative and quantitative data from four schools, two primary and two secondary. However, to support the field work it was decided to develop a research tool that would ensure a structure for the data collection and subsequent analysis and presentation. This had to be sufficiently flexible to allow for differences within and between the schools to be explored whilst also providing a coherence across the research as a whole. It had to enable the complexity of the key concepts to be examined as well as the ambiguity in the nature of the relationship between them. To undertake this work, the Framework for Participation was developed. Thus, it became the research tool used to construct the case studies of the four schools, as well as the methodological lens through which they were examined. It guided decisions about interviews (what to ask and from whom), observations (who to see, where, what, and how to record), documentary and archival sources (what to collect), and statistical data (what to use).

House of Commons, Education and Skills Committee. Special educational needs. Third Report of Session 2005-06, Vol. I (HC 478-I), 2006, London: HMSO, p. 6.

Black-Hawkins, K., Florian, L. and Rouse, M. Inclusion and achievement in schools. London: Routledge, 2007.

Gould, S.J. Life's grandeur: The spread of excellence from Plato to Darwin. London: Jonathan Cape, 1996. 


\section{THE EVOLUTION OF THE FRAMEWORK FOR PARTICIPATION}

Of course, the Framework did not emerge from a methodological or conceptual void: rather it drew on earlier studies that have also explored how inclusion might be understood in the context of achievement. Over the last two decades much of this work has been influenced by a shift in the reconceptualization of inclusion; that is, away from the notion of responding to the identified needs and/or disabilities of a small number of individual children and young people, and towards that of whole school improvement directed at enhancing the learning experiences, or achievement, of all children and young people. Ainscow, ${ }^{7}$ for example, put forward the view that the development of more inclusive schools must necessarily correspond with strategies intended to bring about school improvements more generally. Thus, the focus for many researchers, policymakers, and practitioners has increasingly been on how schools as organizations can change to support all students, rather than on how individual children and young people should fit into existing structures.

At the same time, some researchers have been wary of attempts to encapsulate the notion of an 'inclusive school', arguing against the fatuity of producing "yet another abstract blueprint of the ideal school". ${ }^{8}$ Similarly, Dyson ${ }^{9}$ has criticized research that leads to the production of simplistic inclusive 'checklists' that comprize self-evident items, such as the need for all members of a school to share an inclusive philosophy and belief system. Critics have argued that such findings are truisms and of little value to policy-makers and practitioners who want guidance about how to bring about real changes in real schools. These concerns have helped to develop a strong tradition in this field of research of taking a case study approach: with schools in all their "messiness and inconsistencies" 10 at the centre of the work.

\subsection{School case studies of inclusion and achievement}

The use of a case study approach in the field of inclusive education not only supports the notion of 'the school' as being important (both as a locus for the work and at the level of analysis) but also allows the kind of detailed contextual exploration of schools ${ }^{11}$ that can provide a necessary counter to the criticisms of a checklist approach. As noted earlier, research in inclusive education can be highly problematic because of the elusive nature of its core definitions, concepts, and practices. However, an inherent strength of the case study approach is that it is able to address such concerns precisely because it engages with "the complexity of social activity", ${ }^{12}$ examining the detailed intricacies, uncertainties, and ambiguities of a school, and the experiences of its

Ainscow, M. Understanding the development of inclusive schools. London: Falmer, 1991.

8 Skidmore, D. Inclusion: The dynamic of school development. Maidenhead: Open University Press, 2004, p. 23.

9 Dyson, A. Inclusion and inclusions: theories and discourses in inclusive education. In: DANIEls, H. and GARNER, P. (eds.) Inclusive education, London: Kogan Page, 1999, pp. 36-53.

10 Bоотн, T., and Ainscow, M. (eds.). From them to us: an international study of inclusion ineducation. London: Routledge, 1998 , p. 2.

11 Stake, R.E. Multiple case study analysis. London: The Guildford Press, 2006.

12 Stark, S., and Torrance, H. Case study. In: Research methods in the social sciences, Somekh, B. and Lewin, C. (ed.), London: Sage, 2005, pp. 33. 
members. Furthermore, because it offers the possibility of a more nuanced understanding of education and schools, it has the potential to make an important contribution to a research that is designed to explore the highly complex relationship between inclusion and achievement.

Indeed, over the last decade or so, a considerable number of such studies have been undertaken in which the primary purpose has been to examine various aspects of the concept of inclusion and, either directly or indirectly, its relationship to achievement within the context of real schools. An early example of this is the research undertaken by Thomas, Walker, and Webb ${ }^{13}$ who examined the effects of moving children with physical disabilities from a special school to mainstream provision. The focus of their research was on the attitudes of, and consequences for, members of both forms of schooling over the period of transition. The researchers explained that whilst they had research 'goals' there were "no clear research questions [...] since there search must emerge from the process of research as it proceeds". ${ }^{14}$

Corbett ${ }^{15}$ provides another helpful illustration of a school case study that examines educational inclusion. She deliberately selected a school already well known to her because she considered it to be "exceptionally inclusive". ${ }^{16}$ Not only was this decision integral to her research aims but, as she acknowledges, her assumptions also shaped her methodological approach. Her interest was in practice and specifically what she called "connective pedagogy": ${ }^{17}$ the ways in which staff work to support the learning and achievements of all children, but in particular those identified as having special educational needs. In contrast, Benjamin's ${ }^{18}$ choice of school case study site was more pragmatic: the girls' secondary school in which she taught. Her study did not set out to examine inclusive practices that were 'exceptional' but to scrutinize the ordinary and everyday, by focusing on the "micro politics of inclusive education". ${ }^{19}$ As with the other two studies, Benjamin's interest was in an identified group of learners: young women who were unlikely to achieve academically and for whom it might be argued that their experiences of school had not been inclusive. For this work, Benjamin adopted an open-ended ethnographic approach, in which she was a key participant within her own study.

The purpose of drawing on these examples is to illustrate how a case study approach can support a number of different ways of examining inclusion and achievement and the complex nature of the relationship between them. In each of them, whilst the focus was on identified groups of learners, exploring the context of each school in terms of its organization and cultures was central to the work. Thus, each of these case study approaches allowed a deeper understanding by taking

\footnotetext{
13 Thomas, G., Walker, D. and Webb, J. The making of the inclusive school. London: Routledge, 1998.

Ibid. p. 77.

Corbett, J. Supporting inclusive education: A connective pedagogy. London: Routledge, 2001.

Ibid. p. 3.

Ibid. p. 2.

Benjamin, S. The micropolitics of inclusive education: An ethnography. Buckingham: Open University Press, 2002

Ibid. p. 2.
} 
account of the "lived experiences" 20 of the children and young people within the settings of real schools. This key purpose also underpins the Framework and hence its use to support a multi-site case study within the research project was outlined earlier. However, whilst there are variations in the approaches taken in the three examples of case studies described above, none was structured methodologically in any formal sense: the process of research evolved during the work. This is a significant distinction between these case studies compared with those undertaken using the Framework.

\subsection{The Index of Inclusion: structuring the 'case'}

Using a predetermined structure like the Framework to support a case study approach has its antecedents in the field of inclusive education. Perhaps one of the most widely used is the Index of Inclusion. ${ }^{21}$ Indeed, the Framework shares a number of other important characteristics with the Index. Both are premised on clearly and explicitly articulated principles relating to inclusion. Furthermore, like the Framework, the concerns of the Index are far-ranging: it takes into account the experiences of all members and all aspects of a school. However, the Index is primarily a selfevaluation tool designed to support inclusive whole school improvement: what Ainscow ${ }^{22}$ describes as "school improvement with attitude". Whilst the Framework is underpinned by similar principles, its main purpose is to support research rather than self-evaluation activities, although of course the divide between these two is not always distinct. Moreover, whilst both the Index and the Framework take the whole school as the locus of their exploration, in other ways, their scope is rather different. Because the Index is concerned with supporting school improvement, it is most successful when its processes are sustained and on-going and involve all members of a school. To support this, it offers a comprehensive set of materials based around three 'dimensions' (inclusive cultures, policies, and practices), 44 'indicators' or statements of aspiration, and approximately 500 related 'questions'.

In contrast the Framework is a far more compact set of materials, appropriate to its particular and different purposes. It can certainly aid the collection of research evidence that might then support a process of school's improvement, however it does not set out to be a long-term selfevaluation tool. So, for example, a goal of the Index is, quite appropriately, to help schools to "create inclusive cultures", ${ }^{23}$ whereas the Framework's intention is to examine the cultures of

20 Thompson, E.P. The poverty of theory and other essays. New York: Monthly Review Press, 1978.

21 Boоth, T., Ainscow, M., Black-Hawkins, K., Vaughan, M. and Shaw, L. The Index for Inclusion: Developing learning and participation in schools. Bristol: CSIE, 2000. Whilst originally devised to be used in England and Wales (see RustemiER, S., and Воотн, T. Learning about the Index in use: A study of the use of the Index for Inclusion in schools and LEAs in England. Bristol: CSIE, 2005), the Index has subsequently been translated and developed for use in an increasing number of countries (see, e.g., Воотн, T., and Black-Hawkins, K.. Developing learning and participation in countries of the south: The role of an Index for Inclusion. Paris: UNESCO, 2001; CARrington, S., and Robinson, R. "A case study of inclusive school development: A journey of learning”, in: International Journal of Inclusive Education 8, no. 2, 2004, pp. 141-153; FeArNLEY-SANDER, M., Moss, J. and Harbon, L. "Reading for meaning: Problematizing inclusion in Indonesian civic education", in: International Journal of Inclusive Education 8, no. 2, 2004, pp. 203-219; Engelbrecht, P., Oswald, M. and Florin. C. "Promoting the implementation of inclusive education in primary school in South Africa", in: British Journal of Special Education 33, no.3, 2006, pp. 121-129).

22 Ainscow, M. From special education to effective schools for all: A review of progress so far. In: The Sage handbook of special education. Ed. L. Florian. London: Sage, 2007, p. 157.

23 Boоth, T., Ainscow, M., Black-Hawnins, K., Vaughan, M. and Shaw, L. The Index for Inclusion: Developing learning and participation in schools. Bristol: CSIE, 2000, p. 9. 
a school as they are. Its strength is in its simpler (but not simplistic) construction, offering a manageable tool for researchers, whether academics or practitioners. It acts as a scaffold (but not a check-list) to support the direction of research, in two important ways: first, by prompting systematic and theoretically rigorous reflection, and second, by suggesting a wide range of available sources of evidence to facilitate that research. This is illustrated by the research project, for which the Framework was originally devised. Here it provided a clear structure that enabled four different researchers to collect evidence from four different schools in ways that supported its analysis across and between both the schools and the researchers in a cohesive manner.

\subsection{Large-scale national pupil datasets}

The evolution of the Framework was also shaped by the development of the National Pupil Database (NPD) in England. The NPD contains information about the attainments of students in terms of national standardized test results. Every student in the country is allocated a unique pupil number, allowing individual students' progress to be tracked over time. Furthermore, it is possible to combine these data with the demographic information submitted in the Pupil Level Annual Schools Census (PLASC).As a result, datasets can be produced containing not only details about students with regards to attainment, but also socio-economic status (through eligibility for free school meals and home post code), ethnicity, gender, age, first language spoken, and details of any identified special educational needs. As we have noted elsewhere, this merging of the NPD with the PLASC has made it possible to explore the relationship between achievement and inclusion in ways which previously had not been possible. ${ }^{24}$

In the research project, we were interested in what such a dataset could contribute to our work. On the one hand, it seemed useful to explore questions about the effects of including pupils with special educational needs on the achievement of others. ${ }^{25}$ On the other hand, there was concern that a reliance on the analysis of quantitative data might promote a narrow view of both achievement and inclusion. That is, achievement might be reduced to performance scores in core curriculum subjects, thus disregarding achievements relating to other areas of the curriculum and aspects of children's lives. Similarly, inclusion might be restricted to focusing on the perceived learning difficulties of a small number of individual children, rather than looking more broadly at the contexts in which all teaching and learning takes place. In addition, other concerns emerged about the technical accuracy of the data as well as the aspects relating to its validity and reliability. ${ }^{26}$

Some of these difficulties were acknowledged in research commissioned by the DfES, which also drew on the NPD and PLASC. Dyson (et al.) ${ }^{27}$ measured achievement in terms of the

\footnotetext{
24 Florian, L., Rouse, M., Black-Hawkins, K. and Jull, S. "What can national data sets tell us about inclusion and pupil achievement?”, in: British Journal of Special Education 31, no. 3, 2004, pp. 115-121.

25 Rouse, M., and Florian, L. "Inclusion and achievement: Student achievement in secondary schools with higher and lower proportions of pupils designated as having special educational needs", in: International Journal of Inclusive Education 10, no. 6, 2006, pp. 481-494.

26 Florian, L., Rouse, M., Black-Hawkins, K. and Jull, S. op. cit. (n. 24).

27 Dyson, A., Farrell, P., Polat, F., Hutcheson, G. and Gallannaugh, F.. Inclusion and student achievement (DfES Research Report RR578). Nottingham: DfES, 2004.
} 
academic performance of schools in England according to national test results. Their intention was to examine whether a school's performance was affected, either positively or negatively, by its level of 'inclusivity', as determined by the proportion of students placed on the school's special needs register. However, their findings indicated that generally there was little or no relationship between achievement and inclusion when measured in this way. Furthermore, they recognized that calculating the proportion of students in a school, who have been identified as having special educational needs, says little about how far and in what ways the practices in that school are, or are not, inclusive. Therefore, they supplemented their findings from the datasets with case studies of 16 schools. They argued that, in particular, "There may be something to learn from schools which manage to reconcile high levels of inclusivity with high levels of attainment". ${ }^{28}$ Our scrutiny of the NPD within the research project had led us to similar conclusions, but unlike the Dyson study, we did not use the proportion of students on a school's special needs register as a proxy for inclusion. Rather, we drew on the NPD to select schools that included both higher and lower proportions of students identified as having special educational needs. In addition, we sought the advice of local authority staff to ensure that all four schools enrolled a diverse student population from their local communities and were approaching the task of becoming more inclusive and raising achievement in a variety of ways. We then used the Framework to structure detailed case studies of these schools, so as to develop a deeper understanding of the complex relationship between achievement and inclusion and what this might mean in different settings.

\section{THE FRAMEWORK FOR PARTICIPATION: PRINCIPLES, PURPOSES, AND STRUCTURE}

One further study ${ }^{29}$ was crucial to the evolution of the Framework, including the development of its principles, purposes, and structure. The aim of this work was to examine ways in which the cultures of a school support and/or impede opportunities for all its members to participate in the life of that school. Indeed, understanding the relationship between school culture and the development of more inclusive policies and practices has been important to educationalists for some years now. ${ }^{30}$ Similarly, it was a consideration, either explicitly or implicitly, in each of the studies referred to in the previous section.

Central to the author's earlier work was an in-depth study which examined how school cultures are constituted, reproduced, and changed. ${ }^{31}$ A number of elements were identified as shaping and constraining those cultures, and the inter-relationship between these elements and the values and

$28 \quad$ Ibid. p. 50.

29 Black-Hawkins, K. “Understanding school cultures: Developing participation”. Unpublished PhD diss., The Open University, 2002.

30 See, e.g., Carrington, S. "Inclusion needs a different school culture", in: International Journal of Inclusive Education 3, no. 3, 1999, pp. 257-268; CoRbett, J. "Inclusive education and school culture", in: International Journal of Inclusive Education 3, no. 1, 1999, pp. 53-61; Kugelmass, J. "Collaboration and compromise in creating and sustaining an inclusive school", in: International Journal of Inclusive Education 5, no. 1, 2001, pp. 47-65; Nind, M., Benjamin, S., Sheehy, K., Collins, J. and HaLl, K.. "Methodological challenges in researching inclusive school cultures", in: Educational Review 56, no. 3, 2004, pp. 259-270; Mitchell, D. What really works in special and inclusive education: Using evidence-based teaching strategies. London: Routledge, 2008.

31 Black-Hawkins, K. op. cit. (n. 29), pp. 290-291. 
beliefs held by students and staff was examined. The elements comprised: cultural boundaries of time and space; the relationship between cultures and the lives of individuals; the potency of identity and belonging; the role of language and ideology; the uses and misuses of power and control; understandings of 'normal' and 'other' behaviours; and the prevalence of emotions in the daily life of a school. ${ }^{32}$

This conceptual understanding of school culture, and each of its composite elements, was explored in depth in terms of the participation of members in a school's community. Participation was seen as a way of bringing together the notions of inclusion and achievement, and in so doing, broadening and strengthening the conceptualization of both. This view of participation, developed through this research and its examination of school cultures, was then used to underpin each of the principles of the Framework, as discussed in the following section of this article. Thus, in contrast to the view that inclusion and achievement are incompatible, the research argued that inclusion without achievement is of limited value, and likewise there can be little worthwhile achievement without inclusion. The following definition by Booth is also useful here:

"Participation in education involves going beyond access. It implies learning alongside others and collaborating with them in shared lessons. It involves active engagement with what is learnt and taught, and having a say in how education is experienced. But participation also involves being recognised for oneself and being accepted for oneself. I participate with you, when you recognise me as a person like yourself, and accept me for who I am.” 33

That is, if a school's community aims to support its students (and staff as well) to participate in these ways, then opportunities must be provided for everyone to be included and to achieve. The strength of the connection between these two concepts is paramount. Thus, the inclusion of a child in a school has little meaning unless s/he also experiences achievement, and that child is unlikely to achieve unless s/he are included, which in turn necessitates her/his participation.

Nevertheless, as a concept, participation (indeed, rather like culture, inclusion, and achievement) can be a slippery and elusive term. Pirrie and Head, ${ }^{34}$ for example, provide a forceful critique of its use and misuse. They criticize both governments and academics for providing unhelpful, inaccurate, and even 'banal' interpretations, and they are particularly scathing of "the notion of 'full participation", describing it as a "chimera". They state: "The point, simply, is that participation is not a constant. The degree to which an individual (or indeed a group) participates can vary according to circumstances". ${ }^{35}$ However, the Framework does not promote the notion that participation is ever 'fully' attainable or that it is unchanging, but rather that it requires our careful vigilance: it is not a state that can somehow be arrived at or fixed. As Sfard

\footnotetext{
32 See Ibid. pp. 291-298 for further details.

33 Воотн, T. Inclusion and exclusion in the city: Concepts and contexts. In: Inclusion in the city. Pоттs, P. and Booth, T. (Ed.). London: Routledge, 2002, p. 2.

34 Pirrie, A., and Head, G. "Martians in the playground: Researching special educational needs" in: Oxford Review of Education 33, no. 1, 2007, pp. 19-31.

$35 \quad$ Ibid. p. 24.
} 
argues, participation can be a most useful "metaphor" 36 for educationalists because it "promotes an interest in people in action rather than in people 'as such"' ${ }^{37}$ Although her concern is primarily with processes of learning, her focus on 'action' has a strong resonance with the intentions of the Framework.

\subsection{The principles of the Framework}

Table 1 . What is participation?

Participation ...

1. impacts upon all members of a school and all aspects of school life;

2. is a never-ending process, closely connected to barriers to participation;

3. is concerned with responses to diversity;

4. is distanced conceptually from notions of 'special educational needs';

5. requires learning to be active and collaborative for all;

6. necessitates the active right of members to 'join in'; and

7. is based on relationships of mutual recognition and acceptance.

The seven key principles (see Table 1) that underpin the Framework draw directly on the earlier study. ${ }^{38}$ In so doing, they intend to provide a more subtle and detailed appreciation of the concept of participation, not least as a counter to criticisms such as those set out by Pirrie and Head. ${ }^{39}$ Integral to the principles are the values and beliefs formed within the cultures of a school, which shape and are shaped by the participation of students and staff. These principles also acknowledge that participation will, and sometimes should, vary for different members within and across schools, and that such variations are partly influenced by broader social, economic, and political factors. The details of each principle are discussed below.

Principle 1: Participation impacts upon all members of a school and all aspects of school life.

Participation, because it concerns both achievement and inclusion, necessarily relates to the experiences of all members of a school: staff and parents/carers, as well as students. It does not therefore only apply to a specific group, or groups, of students categorized as having special educational needs. Indeed, using this term to describe students may act as a barrier to their participation. ${ }^{40}$ Similarly, participation is also concerned with all aspects of the life of a school and not just the teaching and learning which occur in classrooms, although this too is important. It relates to a school's formal policies and practices as well as the countless daily interactions that take place amongst its members.

\footnotetext{
36 SfARD, A. "On two metaphors for learning and the dangers of choosing just one", in: Educational Researcher 27, no. 2, 1998 , p. 4.

$37 \quad$ Ibid. p. 8.

38 Black-Hawkins, K. op. cit. (n. 29).

39 Pirrie, A., and Head, G. op. cit. (n. 34).

40 Boоth, T., Ainscow, M., Black-Hawnins, K., Vaughan, M. and Shaw, L. The Index for Inclusion: Developing learning and participation in schools. Bristol: CSIE, 2000.
} 
Principle 2: Participation is a never-ending process, closely connected to barriers to participation.

To make sense of participation, it is necessary to understand its close relationship to barriers to participation: increasing participation reduces barriers to participation and vice versa. However, these processes are not always easy to identify. They can be complex, ambiguous, and opaque. Activities in a school may increase participation for some whilst reinforcing barriers to participation for others. These interconnected and never-ending processes are constantly shifting and may be difficult to change. ${ }^{41}$ Whilst there can be no such institution as a fully participatory one, it is an aspiration well worth pursuing.

Principle 3: Participation is concerned with responses to diversity.

Participation is concerned with responses to all forms of diversity within a school. These include understandings of, and attitudes towards, ethnicity, ${ }^{42}$ gender, ${ }^{43}$ class, ${ }^{44}$ disability, ${ }^{45}$ and ability. ${ }^{46}$ As demonstrated in all these texts, discrimination is often subtle and complex, sometimes unintended, and rarely straightforward; see, for example, Gillborn and Youdell's ${ }^{47}$ exploration of the interplay between poverty, class, ethnicity, and gender in the educational experiences of students. However, the devaluation of any member of a school, for whatever reasons, forms a barrier to their participation. This is not to suggest that all students receive identical learning experiences but rather that their diversity is recognized and used 'as a rich resource to support the learning of all'. ${ }^{48}$ Thus, it is about being equitable towards learners; it is not about denying differences between them.

41 Ballard, K. "Inclusion in practice: a case study of methatheory and action". Paper presented at the symposium of Inclusion and Exclusion in Cambridge University, July 1995; DFES (Department for Children, Schools and Families). Inclusive schooling: Children with special educational needs. London: DfES, 2001.

42 E.g. Blair, M., and Bourne, J. with Coffin, C., Creese, A. and Kenner, C. Making the difference: Teaching and learning strategies in successful multi-ethnic schools. (DfEE Research Report 59). London: HMSO, 1998; RIEHL, C. "The principal's role in creating inclusive schools for diverse students a review of normative, empirical and critical literature on the practice of educational administration”, in: Review of Educational Research 70, no. 1, 2000, pp. 55-81.

43 E.g. Riddell, S. Gender and the politics of the curriculum. London: Routledge, 1992; Siraj-BlatchFord, I. (ed.). Race, gender and the education of teachers. Buckingham: Open University Press, 1993; Blyth, E., and Milner, J. Black boys excluded from school: Race or masculinity issues?. In: Exclusion from school: Inter-professional issues for policy and practice. BLYTH and, E, Milner, J. (Ed.), London: Routledge, 1997, pp. 62-75; Reay, D. 'Troubling, troubled and troublesome?' Working with boys in the primary classroom. In: Boys and girls in the primary classroom, Skelton, C. and Francis, B. (ed.), Open University Press: Maidenhead, 2003, pp. 151-166; Warrington, M., and Younger, M. with Bearne, E. Raising boys' achievement in primary schools: Towards an holistic approach. Maidenhead: Open University Press, 2006.

44 E.g. Gazeley, L., and Dunne, M. Addressing working class underachievement. 2005. http://www.multiverse.ac.uk/ attachments/795dff33-15b54f5a8f9ed5b728e5759.pdf (accessed July 2009); ReAY, D. "The zombie stalking English schools: Social class and educational inequality”, in: British Journal of Educational Studies 54, no. 3, 2006, pp. $288-307$.

45 E.g. Oliver, M. The politics of disablement. Basingstoke: Macmillan, 1990; Thomas, G., Walker, D. and Webb, J. The making of the inclusive school. London: Routledge, 1998.

46 Hart, S., Dixon, A., Drummond, M.J., and McIntyre, D. Learning without limits. Maidenhead: Open University Press, 2004.

47 Gillborn, D., and Youdell, D. Rationing education: Policy, practice, reform and equity. Buckingham: Open University Press, 2000 .

48 Booth, T., Ainscow, M., Black-Hawkins, K., Vaughan, M. and Shaw, L. op.cit. (n. 40), p. 12. 
Principle 4: Participation is distanced conceptually from notions of special educational needs.

However carefully a word is defined, the ways in which it is understood by others are also partly determined by how they choose to use it themselves. This is not just a matter of word play. The concept of inclusion continues to be shaped by past interpretations and in particular their association with the notion of the physical presence and absence of students in mainstream schools. Indeed, in many texts which argue for a wider whole-school interpretation of inclusion, there has remained an enduring focus on specific groups of students identified as having learning difficulties. ${ }^{49}$ The concept of participation does not carry this burden of the past. And, although participation is, rightly, concerned with physical access to and within schools, this is only one aspect of a much broader understanding of schools and education, which encompasses all students and staff engaging in activities inside and outside classrooms.

Principle 5: Participation requires opportunities for learning to be active and collaborative for all.

Participation requires the active and collaborative learning of students, in which they make choices about what they learn as well as how they work together to support each other's learning, that is, being "actively involved". ${ }^{50}$ This is not, therefore, about 'special' provision for 'special' students who are considered to have learning difficulties. To paraphrase the title of Hart's book, ${ }^{51}$ it is about the enhancement of all students' learning "through innovative thinking", and using available resources, including students and other staff, in creative ways. This understanding of participatory learning can also be extended to include members of staff participating in active and collaborative learning with their colleagues and therefore working towards what Southworth ${ }^{52}$ termed, over a decade ago, a "learning school". ${ }^{53}$ The contribution of all teaching and nonteaching staff, as well as students and parents/carers, should be recognized and differences acknowledged, encouraged, and welcomed because they provide a range of experiences, expertise, and interests that make up the membership of a school.

Principle 6: Participation necessitates the active right of members to 'join in'.

Inclusion may suggest a passivity on the part of members of a school, whereas participation stresses the notion of actively 'joining in'. With the former, therefore, there is a sense of the conditional: members are allowed, even if perhaps encouraged by others, to be included. With the latter, participation is a right that is shared by all. However, this in turn also implies reciprocal

49 Sebba, J., with SAChdev, D. What works in inclusive education? Ilford: Barnardo's, 1997; Thomas, G., Walker, D. and WebB, J. op. cit. (n. 13); CoRbetт, J. "Inclusive education and school culture", in: International Journal of Inclusive Education 3, no. 1, 1999, pp. 53-61.

50 Hopkins, D., Black-Hawkins, K., Aldrige, K., LaY, H., Jewell, P. and Davidson, D. Report from the United Kingdom. In: Active learning for students and teachers, Stern, D. and Huber, G. (ed.), Frankfurt: Peter Lang/OECD, 1997, pp. 108-114.

$51 \quad$ Hart, S. Beyond special needs: Enhancing children's learning through innovative thinking. London: Paul Chapman, 1996.

52 Southworth, G. The learning school. In: Improving education: Promoting quality in schools, RibBens, P. and BurRidGe, E. (ed.), London: Cassell, 1994, pp. 52-73.

53 See also Mclaughlin, C., Black-Hawkins, K., and McIntyre, D. with Townsend, A. Networking practitioner research. London: Routledge, 2007. 
responsibilities. That is, there is a right and a responsibility to participate in learning alongside and with others, as well as aright and a responsibility to participate in decision-making processes; see also Macmurray ${ }^{54}$ in the principle below.

Principle 7: Participation is based on relationships of mutual recognition and acceptance.

There are useful parallels between the concept of participation and Fielding' ${ }^{55}$ understanding of the nature of "schools as communities" 56 and "person-centred" schools. In both the quality of relationships between members of a school is crucial. Fielding draws on the work of the philosopher Macmurray ${ }^{57}$ who argued that relationships should be based on the two fundamental principles of freedom and equality:

"If we do not treat one another as equals, we exclude freedom from the relationship. Freedom too, conditions equality. For if there is restraint between us there is fear; and to counter the fear we must seek control over its object, and attempt to subordinate the other person to our own power. Any attempt to achieve freedom without equality, or to achieve equality without freedom, must, therefore be self-defeating." 58

This emphasis on 'freedom' and 'equality' also relates to the rights and responsibilities noted in the sixth principle. That is, members have the right to be themselves whilst accepting the responsibility for valuing other members as their equals. Macmurray, ${ }^{59}$ however, does not define equality in terms of assimilation, stating: "It is precisely the recognition of difference and variety amongst individuals that gives meaning to the assertion of equality" ${ }^{60}$ All relationships in schools require recognition and acceptance: those between students and staff as well as those amongst students and amongst staff. And, they are enacted not only through policies and practices, but also in the countless informal personal interactions that take place amongst students and staff in any school.

\subsection{The purposes of the Framework}

As already discussed, the Framework was first devised as a research tool, or methodological lens, to support the collection, analysis, and presentation of data from the four schools that comprised a multi-site case study. It allowed us to scrutinize the policies, practices, and everyday interactions

Macmurray, J. Conditions of freedom. London: Faber, 1950.

55 Fielding, M. "The person-centred school”, in: Forum 42, no. 2, 2000, pp. 51-54; Fielding, M. "Leadership, radical student engagement and the necessity of person-centred education", in: International Journal of Leadership in Education 9, no. 4, 2006, pp. 299-313.

56 Fielding, M. "Community, philosophy and education policy: Why effective policies won't work". Paper presented at the annual conference of the British Educational Research Association at Queen's University, Belfast, August 1998; Fielding, M. Communities of learners. Myth: Schools are communities. In: Modern educational myths, O’Hagan, B. (ed.), London: Kogan Page, 1999, pp. 67-87.

57 Macmurray, J. Conditions of freedom. London: Faber, 1950.

$58 \quad$ Ibid. p. 74.

59 Macmurray, J. The clue to history. London: Student Christian Movement Press, 1938.

$60 \quad$ Ibid. p. 4. 
that contributed to the life of the four schools, and, in doing so, to explore key themes and concerns regarding the relationship between inclusion and achievement. As part of this the research team wanted to consider how related concepts were understood and used by a range of members within the schools and the consequences of those different meanings and applications. Hence, the research project was interested in various understandings of ideas associated with inclusion, such as exclusion, integration, special educational needs, difficulties in learning and disability, as well as broader notions of social and economic inclusion and exclusion. Likewise, meanings of achievement and related ideas were explored, including academic standards, attainment, progress, performance, aptitude and ability, plus wider conceptualizations of educational achievement. ${ }^{61}$ Thus, the research was also interested in members' underlying beliefs about notions such as "same" and "different", "normal" and "other". ${ }^{62}$

The Framework also supported a consideration of how these issues interacted at different levels within and between the four schools: that is, an understanding of the educational experiences not only of an individual child or young person, but also a particular group of students or class, as well as across a whole school and beyond, including local and national influences and concerns. It was able to take account of the participation of a wide range of members of a school, including students, teachers, support staff, and parents/carers. It set out to understand why one school may be more successful than another, often similar school, at supporting both the inclusion and achievement of its members. It was also concerned with exploring the underlying values and beliefs embedded in the cultures of the schools and identifying existing and potential strategies to raise achievement and inclusion and, thereby, to become increasingly participatory.

The key purposes of the Framework, as discussed throughout this article, are summarized here. These are to:

- Examine the participation of all members of a school: students, teaching and non-teaching staff, and parents/carers;

- Explore the complexities of the educational experiences of individual and groups of children and young people and staff, as well as across whole classes, schools, and beyond;

- Address why some schools are more successful than other similar schools at supporting both the inclusion and achievement of students and staff;

- Scrutinize a school's policies and practices and everyday interactions so as to reveal the underlying values and beliefs embedded in its cultures; and

- Identify existing and potential strategies which are effective in raising achievement and inclusion, as well as those which may reduce barriers to achievement and inclusion.

61 See Black-Hawnins, K., Florian, L. and Rouse, M. Inclusion and achievement in schools. London: Routledge, 2007, for an analysis of these terms.

62 Florian, L. Reimagining special education. In: The Sage handbook of special education, Florian, L. (ed.), London: Sage, 2007 , pp. 7-20. 
Not only are all five purposes closely connected, but they can also lead to what appear to be contradictory findings. That is, certain policies or practices may promote greater participation for some members of a school whilst reinforcing barriers to participation for others. Indeed, the impact of some policies and practices even on individual members may be ambivalent. One commonplace example identified in all four schools was the practice of withdrawing students with low literacy levels from mainstream lessons so as to provide small group intensive teaching in reading and writing. Such provision arguably both supported and impeded their participation. On the one hand, improved literacy competence would allow such students greater access to the curriculum in the future. On the other hand, their withdrawal excluded them from the current learning experiences of their peers in mainstream classes. Clark (et al.) ${ }^{63}$ describe this as the "commonality-difference dilemma" ${ }^{44}$ They argue that if the staff respond to students' diversity, they "ipso facto create different forms of provision for different students and thus become less than fully inclusive". Yet, if the staff ignore students' diversity, they may exclude them from participation by "offering them experiences from which they [are] alienated". ${ }^{65}$ The Framework did not attempt to smooth away these everyday complexities, but to provide a means by which they could be more clearly understood. In each of the four schools, it was perhaps the values and beliefs underpinning the rationale for policies and practices that required our most careful consideration.

\section{3.-Structuring the Framework}

Table 2. Sections of the Framework for Participation.

1. Participation and ACCESS: being there

2. Participation and COLLABORATION: learning together

3. Participation and DIVERSITY: recognition and acceptance

The Framework is divided into three main sections as shown in Table 2. These provide the overall structure by which the principal elements of participation can be considered. Each section relates to an aspect of what it means to participate, or not to participate, in the life of a school.

Table 3. Elements and questions of the Framework for Participation.

1. Participation and ACCESS: being there

Joining the school

\Staying in the school

囚Access to spaces and places

63 Clark, C., Dyson, A., Millward, A. and Robson, S. "Theories of inclusion, theories ofschools: Deconstructing and reconstructing the inclusive school”, in: British Educational Research Journal 25, no. 2, 1999, pp. 157-177.

$64 \quad$ Ibid. p. 171.

$65 \quad$ Ibid. p. 172. 
$\otimes$ Access to the curriculum

- Who is given access and by whom? Who is denied access and by whom?

-What are the policies, practices, and interactions that promote access? What are the policies, practices, and interactions that reinforce barriers to access?

-Why within the cultures (values and beliefs) of the school is greater access afforded to some individuals/groups? And, why is access withheld from some individuals/ groups?

2. Participation and COLLABORATION: learning together

$\nabla$ Learning alongside other students

$\nabla$ Supporting students to learn together

Мembers of staff working together

\Staff and students learning together

Q Schools and other institutions working together

_ Who learns together? Who does not learn together?

_ What are the policies, practices, and interactions that promote collaboration? What are the policies, practices, and interactions that reinforce barriers to collaboration?

_Why within the cultures (values and beliefs) of the school do some individuals/ groups learn together? And, why are there barriers to some individuals/groups learning together?

3. Participation and DIVERSITY: recognition and acceptance

$\nabla$ Recognition and acceptance of students, by staff

$\otimes$ Recognition and acceptance of staff, by staff

$\otimes$ Recognition and acceptance of students, by students

-Who is recognized and accepted as a person and by whom? Who is not recognized and accepted as a person and by whom?

-What are the policies, practices, and interactions that promote recognition and acceptance? What are the policies, practices, and interactions that form barriers to recognition and acceptance?

-Why within the cultures (values and beliefs) of the school are some individuals/ groups recognized and accepted? And, why are there barriers to the recognition and acceptance of some individuals/groups? 
The next stage of the Framework is shown in Table 3. Here each of the three main sections are expanded to include a number of related elements, accompanied by a series of questions, to help determine decisions about what evidence to collect, from whom, and how. In many ways, it is the 'why' questions in Table 3 that are most pertinent in understanding participation, for in addressing these, the reasons and purposes underlying 'who' and 'what' are more easily revealed. To make sense of 'why' necessitates an exploration of the underlying values and beliefs which shape the cultures, and thus the policies and practices and everyday interactions, of a school. The experience of using the Framework in the four case study schools suggests that such scrutiny can take time because of the need to develop a level of trust in relationships with school members. However, this research also suggests that these intentions are well worth pursuing.

Of course, the three main sections that structure the Framework are unlikely to be experienced by staff and students as discrete entities within a school. Therefore, as researchers, choosing where to include specific aspects of participation is not always straightforward. 'Participation and diversity', in particular, permeates all policies and practices. For example, decisions about admissions within 'participation and access' are likely to be partly based on understandings of and attitudes towards student diversity. Similarly, successful 'participation and collaboration' will be, to some extent, dependent upon the acknowledgement of members that the range of experiences and expertise amongst them is a resource that may enrich the learning of students and staff, rather than simply a problem to be overcome. And, of the three main sections, that of 'participation and diversity' is probably the most problematic in terms of identifying processes of and barriers to participation. This is not only to do with its pervasiveness, but also because the values and beliefs which underpin relationships between members of any school are often unquestioned by staff and students alike.

Table 4. Extract from evidence to support the Framework for Participation.

Access to spaces and places

叉 Physical accessibility policies and practices

-For students $(\mathrm{D}+\mathrm{O}+\mathrm{I})$

- For staff $(\mathrm{D}+\mathrm{O}+\mathrm{I})$

- For parents/carers and other visitors $(\mathrm{D}+\mathrm{O}+\mathrm{I})$

-Attitudes towards increasing physical access for members of the school (I)

$\otimes$ Creating and maintaining a welcoming and safe school

- Induction policies and practices for new students (D + I)

-Induction policies and practices for all new staff $(\mathrm{D}+\mathrm{I})$

- Anti-bullying policies (D) 
- Practices to help bullies and their victims (I)

- Stories of bullying (I)

-Welcoming/safe or frightening places: for whom, why, and-when? $(\mathrm{O}+\mathrm{I})$

-Practices and attitudes about rules, rewards, and sanctions $(\mathrm{I}+\mathrm{O})$

-Open or out-of-bounds places: for whom, why, and when? $(\mathrm{O}+\mathrm{I})$

- Policies around rules, rewards, and sanctions (D)

Note: $\mathrm{D}=$ documents, $\mathrm{O}$ = observations, and $\mathrm{I}$ = interviews.

Finally, there is a fourth stage of the Framework, which cannot be reproduced here because of its length. ${ }^{6}$ It builds on the Framework's sections, elements, and questions by providing suggestions for the collection of evidence that is likely to be available to researchers, including practitioners. It comprises ideas for interviews, observations, and documentation (plus statistical data), although, of course, there are many other research methods which might be added. Table 4 provides an illustrative extract relating to the element 'Access to spaces and places' (from Section 1 of the Framework, 'Participation and Access: Being There'). The fourth stage is a resource which can be developed and supplemented in ways which suit different researchers' particular concerns, interests, and needs. So, for example, if research is focused on 'creating and maintaining a welcoming and safe school' (as part of 'access to spaces and places') in addition to the suggestions given in Table 4, researchers might also ask students to record, by taking photographs or using a video camera, those places and spaces in their school where they do, and do not, feel safe.

\section{USING THE FRAMEWORK IN THE RESEARCH PROJECT: A MULTI-SITE CASE STUDY}

The research was based on two primary and two secondary schools, all situated in the same urban area. As noted earlier, two criteria were applied when selecting the schools: that they enrolled a diverse student population from their local communities, and that they were clearly seeking to develop the achievement of all their students within the context of maintaining an inclusive student intake. However, whilst all four schools shared these characteristics, it was anticipated that the policies and practices which they had developed to support the inclusion and achievement of their students would vary across and within each of the schools in response to their own particular priorities, challenges, and resources. A central purpose of the Framework was to structure the gathering of evidence so as to illustrate the wide range of approaches that different practitioners had adopted as they sought to understand, monitor, and develop their students' achievement and inclusion.

The project drew on Stake ${ }^{67}$ to support the methodological rationale for a multi-site case study. He stresses the importance of describing the overall phenomenon that is being investigated, and

66 See Black-Hawkins, K., Florian, L. and Rouse, M. op. cit. (n. 61), pp. 149-152 for full version. 
argues that "complex meanings ... are understood differently because of the particular activity and contexts of each Case". ${ }^{68}$ The intention of the project was not to seek for broad generalizations across the four schools but rather to gain a clearer knowledge of the whole by considering both commonalities between and variations amongst them. As Stake explains: "Comprehension of the phenomenon ... requires knowing not only how it works or does not work in general, independent of local conditions, but how it works under various local conditions" ${ }^{69}$ Therefore, looking across four schools offered the possibility of a deeper understanding of the complex phenomena of educational achievement and inclusion, and the relationship between them, as experienced by students and staff.

The research team visited the schools over the course of about six months, spending an equivalent of approximately eight days in each school. However, before the fieldwork began, we planned our visits using the Framework. We started by taking each one of its three sections ('access', 'collaboration', and 'diversity') in turn. We focused on their elements and considered how we might address their accompanying 'who?', 'what?', and 'why?' questions (see Table 3). We then drew on the fourth part of the Framework to help us to identify sources of evidence to support this and which were likely to be available in the schools (see extract in Table 4). This stage of the preparation, however, was cyclical in nature, because in seeking ways to address some questions, we also devised additional evidence sources, and vice versa.

Throughout, we aimed to use a variety of methods (interviews and informal conversations, observations, documents, and statistical data), involving a range of different members (students, teachers, head teachers, support staff, and parents/carers) and in diverse situations (at work and play, in classrooms, staffrooms, play grounds, corridors, meetings, assemblies, and canteens). Since both inclusion and achievement are complex and uncertain concepts, we were keen to engage in "research [that] provides a source for exposing, even for creating, ambiguity" ${ }^{70} \mathrm{We}$ did not seek for consistency between, and even within, members of, and situations in, each school. Amongst many other examples that could be given, we were interested in exploring differences and similarities between:

- A school's written policies and the ways in which those policies were enacted in observed practice;

- The values and beliefs ascribed to by a teacher in interview and how those values and beliefs were demonstrated in that teacher's observed relationships with others in the school;

- The observed behaviour of students in one lesson and how they behaved in other lessons;

- How a teacher was observed speaking to students in lessons and how s/he talked about the same students to colleagues in the staffroom as well as during interviews;

$68 \quad$ Ibid. p. 40.

69) Ibid.

70 Walker, R. Social research as a deviant activity. In: Biography, identity and schooling: Episodes in educational research, Goodson, I.F. and Walker, R. (ed.), London: The Falmer Press, 1991, p. 106. 
- How a teaching assistant was observed responding to a learner identified as having special educational needs and how a class teacher was similarly observed; and

- How a learning support co-ordinator described the needs of a student in an interview and how the same student articulated what s/he wanted.

Once we were clear who we needed to talk to and what we would like to see, we also used the Framework's elements and questions to help to construct the schedules for our semi-structured interviews and observations, as well as to compile an inventory of the school documents and data from the NPD and PLASC that we wanted to examine. By working in this way, once the fieldwork was completed, we were able to return to the sections, elements, and questions to structure the analysis, discussion, and presentation of the findings from each individual school.

Finally, the structure of the Framework was crucial in terms of supporting the research across the four schools within the multi-site case study. We sometimes visited the schools and classrooms in pairs and sometimes individually. Whilst the Framework allowed sufficient flexibility for each of us to pursue what was of interest in a range of particular and varying contexts, it also provided a coherent structure for discussion when individuals' findings were shared, thus making it possible for us to consider as a team what counted as evidence, including in the final stages of analysis and writing. In this way, we were able to identify commonalities amongst and variations between the schools in terms of our examination of the relationship between achievement and inclusion, and so deepen our "comprehension of the phenomenon". ${ }^{71}$

\section{REFLECTING ON THE USE OF THE FRAMEWORK}

Thus far, the original study indicates that the Framework provides a coherent and flexible structure to support the collection of data from individual schools and across a multi-site case study, suggesting that it is a helpful tool for researchers who wish to examine more deeply the nature of the relationship between achievement and inclusion. There are, of course, a number of other such useful resources available, as previously discussed, and the Framework should be seen as complementing these. The concluding section of this article considers the particular contribution that the Framework can make to this work.

\section{1.-Practitioner researchers}

During the course of the original project, we realised that the Framework could usefully be adapted to support the research needs of practitioners in schools, and we have subsequently shared the materials with teachers who have, indeed, found them to be helpful. A strength of the Framework is that it can be applied in a flexible manner so as to suit a range of research concerns and interests, as well as the particular circumstances of individual schools and teachers. Furthermore, all of the suggested sources for evidence (see Table 4 for example) are readily available in schools and, thus, are particularly supportive of practitioners who wish to engage in research activities as part of their professional development.

\footnotetext{
STAKe, R.E. op. cit (n. 67).
} 
Whilst the Framework does not specify precisely how interviews might be undertaken, or precisely which aspects of school life might be observed, its structure of elements, questions, and evidence sources offers helpful guidance. Furthermore, the experience of using the Framework in the original project, as well as when supporting the research of practitioners, suggests that asking members of a school to provide narrative accounts of events can be particularly revealing of their values and beliefs as well as the ways in which these are interwoven into the [school's] "own narrative history of shifting values, beliefs and stories". ${ }^{72}$ Thus, in Table 4, one such suggestion is asking students, staff and/or parents/carers to relate 'stories of bullying'. Other examples used by practitioner-researchers include: a teacher telling a story about why a child has been excluded; a teaching assistant describing a lesson in which s/he worked really well in collaboration with a teacher; and a student relating how s/he spends her/his lunchtimes. Similarly, practitioners' experiences of observations indicate that not only lessons, but also staffrooms, assemblies, playgrounds, canteens, and staff meetings can provide real opportunities to explore, for example, how far policies are put into practice, as well as the nature of the relationships between members of a school. In practical terms, these other situations are also often more accessible for practitionerresearchers who may not be easily released from their own teaching commitments to observe the lessons of their colleagues.

\section{2.-Future developments of the Framework}

Not only can the Framework be used flexibly in a range of different ways but that the structure itself is also open to modification. Indeed, members of the original research team are currently in the process of adapting it to reflect our developing research interests. ${ }^{73}$ We are now focusing more closely on the nature of the relationship between educational achievement and inclusion as part of the daily routines and practices of classrooms. That is, we have become increasingly interested in understanding in detail the teaching and learning approaches and strategies which support the achievement of all children, including those who are designated as having special educational needs. Hence, we are currently trialling, in two primary schools, a new version of the Framework, which has an additional section on 'Participation and achievement: inclusive pedagogy'. By drawing on the work of Rouse, ${ }^{74}$ the new elements and questions are intended to examine what members of staff 'know', 'believe', and 'do' about inclusive pedagogy. Another important development for us in this research is our intention to research in closer collaboration with staff. Thus, the Framework is not only guiding our research in ways that we hope will allow us to identify and examine examples of inclusive pedagogy in action, but will also enable us, by working with practitioners, to articulate these in ways that will be helpful to other teachers and will be supportive of their classroom practice.

72 Clandinin, D.J., and Connelly, F.M. “Teachers' professional knowledge landscapes: Teacher stories - stories of teachers school stories - stories of schools”, in: Educational Researcher 25, no. 3, 1996, p. 3.

73 Black-Hawkins, K., Florian, L. and Rouse, M. "Achievement and inclusion in schools and classrooms: Participation and pedagogy". Paper presented at the British Educational Research Association Conference in Herriot Watt University, Edinburgh, September 2008.

74 Rouse, M. “Developing inclusive practice: A role for teachers and teacher education?”, in: Education in the North 16, 2008, pp. $6-11$. 


\section{3.-Final thoughts}

Understanding the relationship between inclusion and achievement is of importance to educationalists for a number of reasons, many of which are at the heart of concerns about where and how children and young people should be educated. These include: the pressures on schools brought about by an increased accountability, the justification for allocating additional resources to groups of students, the introduction of national strategies to improve teaching and learning more generally, the development of evidence-based practice, and unease about the morale of teachers and the motivation of students. However, there are undoubtedly real difficulties when research sets out to examine concepts that are considered to be, broadly speaking, as unquestionably just and good as achievement and inclusion. The danger is that such endeavours will result in platitudes that encourage an easy consensus rather than challenge current thinking, let alone shape policy and practice.

The over-riding rationale for the Framework, as set out in this article, is to support this important work by offering a research tool which recognizes the complexity of achievement and inclusion and the relationship between them. This is accomplished partly through the detail of its sections, elements, questions, and variety of its evidence sources, and partly through the provision of a structure which is both supportive and flexible. Moreover, its theoretical underpinnings have been developed by building on previous research which takes account of the complexity of schools as organizations and the ambiguity of the everyday experiences of students and staff. In so doing, the Framework also acknowledges the often huge demands that are made of teachers who wish to support the inclusion and the achievement of all the children they teach. Its fundamental aim is to learn from staff and children in ways which will be useful to them and to others who work in and with schools. The intention of this article is to contribute to that work.

\section{BIBLIOGRAPHY}

Ainscow, M. Understanding the development of inclusive schools. London: Falmer, 1991.

From special education to effective schools for all: A review of progress so far. $\underline{\text { nn: The }}$ Sage handbook of special education. Ed. L. Florian. London: Sage, 2007, pp. 146-159

Audit Commission. Statutory assessment and statements of SEN: in need of review? London: HMSO, 2002.

BALlard, K. "Inclusion in practice: a case study of methatheory and action". Paper presented at the symposium of Inclusion and Exclusion in Cambridge University, July 1995.

Benjamin, S. The micropolitics of inclusive education: An ethnography. Buckingham: Open University Press, 2002.

Black-Hawkins, K. "Understanding school cultures: Developing participation". Unpublished PhD diss., The Open University, 2002. 
Black-Hawkins, K., Florian, L. and Rouse, M. Inclusion and achievement in schools. London: Routledge, 2007.

"Achievement and inclusion in schools and classrooms: Participation and pedagogy". Paper presented at the British Educational Research Association Conference in Herriot Watt University, Edinburgh, September 2008.

Blair, M., and Bourne, J. with Coffin, C., Creese, A. and Kenner, C. Making the difference: Teaching and learning strategies in successful multi-ethnic schools. (DfEE Research Report 59). London: HMSO, 1998.

Blyth, E., and Milner, J. Black boys excluded from school: Race or masculinity issues?. In: Exclusion from school: Inter-professional issues for policy and practice. BLYTH E, and MiLnER, J. (Ed.), London: Routledge, 1997, pp. 62-75.

Воотн, T. Inclusion and exclusion in the city: Concepts and contexts. In: Inclusion in the city. Pоттs, P. and Воотн, T. (Ed.). London: Routledge, 2002, pp. 1-14.

, and Ainscow, M. (eds.). From them to us: an international study of inclusion ineducation. London: Routledge, 1998.

Booth, T., Ainscow, M., Black-Hawkins, K., Vaughan, M. and Shaw, L. The Index for Inclusion: Developing learning and participation in schools. Bristol: CSIE, 2000.

Boотн, Т., and Black-Hawkins, K.. Developing learning and participation in countries of the south: The role of an Index for Inclusion. Paris: UNESCO, 2001.

Carrington, S. "Inclusion needs a different school culture", in: International Journal of Inclusive Education 3, no. 3, 1999, pp. 257-268.

Carrington, S., and Robinson, R. "A case study of inclusive school development: A journey of learning”, in: International Journal of Inclusive Education 8, no. 2, 2004, pp. 141-153.

Clandinin, D.J., and Connelly, F.M. “Teachers' professional knowledge landscapes: Teacher stories - stories of teachers - school stories - stories of schools", in: Educational Researcher 25, no. 3, 1996, pp. 24-30.

Clark, C., Dyson, A., Millward, A. and Robson, S. "Theories of inclusion, theories ofschools: Deconstructing and reconstructing the inclusive school”, in: British Educational Research Journal 25, no. 2, 1999, pp. 157-177.

Corbett, J. "Inclusive education and school culture", in: International Journal of Inclusive Education 3, no. 1, 1999, pp. 53-61.

Supporting inclusive education: A connective pedagogy. London: Routledge, 2001. 
DFES (Department for Children, Schools and Families). Inclusive schooling: Children with special educational needs. London: DfES, 2001.

Dyson, A. Inclusion and inclusions: theories and discourses in inclusive education. In: DANIELs, H. and Garner, P. (eds.) Inclusive education, London: Kogan Page, 1999, pp. 36-53.

Dyson, A., Farrell, P., Polat, F., Hutcheson, G. and Gallannaugh, F.. Inclusion and student achievement (DfES Research Report RR578). Nottingham: DfES, 2004.

Engelbrecht, P., Oswald, M. and Florin. C. "Promoting the implementation of inclusive education in primary school in South Africa”, in: British Journal of Special Education 33, no.3, 2006, pp. 121-129.

Fearnley-Sander, M., Moss, J. and Harbon, L. "Reading for meaning: Problematizing inclusion in Indonesian civic education", in: International Journal of Inclusive Education 8, no. 2, 2004, pp. 203-219.

Fielding, M. "Community, philosophy and education policy: Why effective policies won't work". Paper presented at the annual conference of the British Educational Research Association at Queen's University, Belfast, August 1998.

Communities of learners. Myth: Schools are communities. In: Modern educational myths, O’Hagan, B. (ed.), London: Kogan Page, 1999, pp. 67-87.

"The person-centred school", in: Forum 42, no. 2, 2000, pp. 51-54.

Fielding, M. "Leadership, radical student engagement and the necessity of person-centred education", in: International Journal of Leadership in Education 9, no. 4, 2006, pp. 299-313.

Florian, L. Reimagining special education. In: The Sage handbook of special education, Florian, L. (ed.), London: Sage, 2007, pp. 7-20.

Florian, L., Rouse, M., Black-Hawkins, K. and Jull, S. "What can national data sets tell us about inclusion and pupil achievement?", in: British Journal of Special Education 31, no. 3, 2004, pp. 115-121.

Gazeley, L., and Dunne, M. Addressing working class underachievement. 2005. http://www. multiverse.ac.uk/attachments/795dff33-15b54f5a8f9ed5b728e5759.pdf (accessed July 2009).

Gillborn, D., and Youdell, D. Rationing education: Policy, practice, reform and equity. Buckingham: Open University Press, 2000.

Gould, S.J. Life's grandeur: The spread of excellence from Plato to Darwin. London: Jonathan Cape, 1996.

HarT, S. Beyond special needs: Enhancing children's learning through innovative thinking. London: 
Paul Chapman, 1996.

Hart, S., Dixon, A., Drummond, M.J., and McIntyre, D. Learning without limits. Maidenhead: Open University Press, 2004.

Hopkins, D., Black-Hawkins, K., Aldrige, K., Lay, H., Jewell, P. and Davidson, D. Report from the United Kingdom. In: Active learning for students and teachers, STERn, D. and Huber, G. (ed.), Frankfurt: Peter Lang/OECD, 1997, pp. 108-114

House of Commons, Education and Skills Committee. Special educational needs. Third Report of Session 2005-06, Vol. I (HC 478-I), 2006, London: HMSO.

Kugelmass, J. "Collaboration and compromise in creating and sustaining an inclusive school", in: International Journal of Inclusive Education 5, no. 1, 2001, pp. 47-65.

Macmurray, J. The clue to history. London: Student Christian Movement Press, 1938.

Conditions of freedom. London: Faber, 1950.

Mclaughlin, C., Black-Hawkins, K., and McIntyre, D. with Townsend, A. Networking practitioner research. London: Routledge, 2007.

Mitchell, D. What really works in special and inclusive education: Using evidence-based teaching strategies. London: Routledge, 2008.

Nind, M., Benjamin, S., Sheehy, K., Collins, J. and Hall, K.. "Methodological challenges in researching inclusive school cultures", in: Educational Review 56, no. 3, 2004, pp. 259-270.

Oliver, M. The politics of disablement. Basingstoke: Macmillan, 1990.

Pirrie, A., and Head, G. "Martians in the playground: Researching special educational needs" in: Oxford Review of Education 33, no. 1, 2007, pp. 19-31.

Power, S., and Whitty, G. Market forces and school cultures. In: School culture, Prosser, J. (ed.), London: Paul Chapman, 1999, pp. 15-29.

ReaY, D. 'Troubling, troubled and troublesome?' Working with boys in the primary classroom. In: Boys and girls in the primary classroom, Skelton, C. and Francis, B. (ed.), Open University Press: Maidenhead, 2003, pp. 151-166.

"The zombie stalking English schools: Social class and educational inequality", in: British Journal of Educational Studies 54, no. 3, 2006, pp. 288-307.

RIDDELL, S. Gender and the politics of the curriculum. London: Routledge, 1992.

Rient, C. "The principal's role in creating inclusive schools for diverse students a review of normative, empirical and critical literature on the practice of educational administration”, in: 
Review of Educational Research 70, no. 1, 2000, pp. 55-81.

Rouse, M. "Developing inclusive practice: A role for teachers and teacher education?", in: Education in the North 16, 2008, pp. 6-11.

Rouse, M., and Florian, L. "Inclusive education in the marketplace", in: International Journal of Inclusive Education 1, no. 4, 1997, pp. 323-336.

"Inclusion and achievement: Student achievement in secondary schools with higher and lower proportions of pupils designated as having special educational needs", in: International Journal of Inclusive Education 10, no. 6, 2006, pp. 481-494.

Rustemier, S., and Boоth, T. Learning about the Index in use: A study of the use of the Index for Inclusion in schools and LEAs in England. Bristol: CSIE, 2005.

Sebba, J., with Sachdev, D. What works in inclusive education? Ilford: Barnardo's, 1997.

SFARD, A. "On two metaphors for learning and the dangers of choosing just one", in: Educational Researcher 27, no. 2, 1998, pp. 4-13.

Siraj-Blatchford, I. (ed.). Race, gender and the education of teachers. Buckingham: Open University Press, 1993.

Skidmore, D. Inclusion: The dynamic of school development. Maidenhead: Open University Press, 2004.

Southworth, G. The learning school. In: Improving education: Promoting quality in schools, Ribbens, P. and Burridge, E. (ed.), London: Cassell, 1994, pp. 52-73.

Stake, R.E. Multiple case study analysis. London: The Guildford Press, 2006.

Stark, S., and Torrance, H. Case study. In: Research methods in the social sciences, Somekh, B. and Lewin, C. (ed.), London: Sage, 2005, pp. 33-40.

Thomas, G., Walker, D. and Webb, J. The making of the inclusive school. London: Routledge, 1998.

Thompson, E.P. The poverty of theory and other essays. New York: Monthly Review Press, 1978.

Walker, R. Social research as a deviant activity. In: Biography, identity and schooling: Episodes in educational research, Goodson, I.F. and Walker, R. (ed.), London: The Falmer Press, 1991, pp. 94-106.

Warrington, M., and Younger, M. with Bearne, E. Raising boys' achievement in primary schools: Towards an holistic approach. Maidenhead: Open University Press, 2006. 